\title{
FAKTOR PENYEBAB KETERLAMBATAN PEKERJAAN KONSTRUKSI MENURUT PRESEPSI KONTRAKTOR
}

\begin{abstract}
Abstrack
Jambi city is one of the develop cities in Sumatera Island, especially on infrastructure and the economy.Construction is one activity that is enhanced by the local government in the framework of the welfare and prosperity of the people of Jambi. Alongconstruction period, delays in work is still very common problems. There are many factors causing delays become very common problem faced by the parties involved, especially the Contractor which act as implementers.

The research of the factors causing delays in construction work in the city of Jambi as perceived by the contractor, found number of conclusions, among others:Factors Materials and Materials obtain a total score of 7.18,Environmental Factors obtain a total score of 5.96,Financial Factor obtain a total score of 5.99,Factors Changes obtain a total score of 6.95, The Labor get highest total score is 7.29,Factors and Control Time to get a total score of 5.93,Factors Hardware obtain a total score of 7.15
\end{abstract}

\section{PENDAHULUAN}

Kota Jambi adalah salah satu kota yang mulai berkembang di pulau Sumatera dalam bidang infrastruktur maupun ekonomi.Pembangunan bidang infrastruktur adalah salah satu kegiatan yang ditingkatkan oleh pemerintah setempat dalam rangka mensejahterakan dan memakmurkan masyarakat Kota Jambi.Pada saat ini kota Jambi jumlah masyarakatnya selalu bertambah, dengan adanya masalah tersebut, maka pihak yang terkait nantinya akan melakukan tindakan antisipasi, salah satunya dengan cara melakukan pembangunan perumahan.

Sangat penting bagi kontraktor untuk menyelesaikan pekerjaan tepat waktu, karena hal itu akan menguntungkan bagi owner, kontraktor, konsultan dan pihakpihak lain yang berperan dalam kegiatan. Dan sebaliknya keterlambatan pekerjaan akan sangat berpengaruh terhadap reputasi kontraktor.Pihak owner biasanya akan lebih banyak mempercayakan suatu kegiatan konstruksi kepada kontraktor yang berprestasi dan memiliki reputasi yang baik.Jadi ketepatan waktu pekerjaan bisa dikatakan adalah suatu keharusan bagi kontraktor agar bisa mendapat kepercayaan dari pihak pemilik kegiatan. 
Keterlambatan adalah hal yang sangat berpengaruh terhadap keberhasilan suatu pekerjaan, keterlambatan akan sangat merugikan bagi seluruh pihak yang terlibat di dalam suatu industri konstruksi.

Oleh karena itu, penulis melakukan penelitian "faktor penyebab keterlambatan pekerjaan konstruksi di kota Jambi menurut persepsi kontraktor" agar pihak pelaksana pekerjaan dapat lebih mengantisipasi serta memikirkan solusi yang efektif dan efisien apabila terjadi masalah pada saat proses pekerjaan sedang berlangsung.

Adapun tujuan dari penelitian ini adalah sebagai berikut :

1. Mengidentifikasi permasalahan yang dihadapi kontraktor yang menyebabkan keterlambatan pekerjaan.

2. Mengetahui faktor-faktor apa saja yang mempengaruhi keterlambatan pekerjaan.

3. Mencari faktor yang paling dominan dalam keterlambatan pekerjaan konstruksi.

Menurut Soeharto (1995), proyek adalah kegiatan sekali lewat, dengan waktu dan sumber daya terbatas untuk mencapai hasil akhir yang telah ditentukan, misalnya produk atau fasilitas produksi.

Menurut Wulfram (2002), proyek adalah suatu rangkaian kegiatan yang hanya satu kali dilaksanakan dan umumnya berjangka waktu pendek.

Menurut Levis dan Artherley (1996), pada 30 proyek bangunan gedung di telah dapat di identifikasikan beberapa penyebab keterlambatan, yaitu antara lain:

1. Keterlambatan pembayaran oleh client owner

2. Pelaksanaan tahapan pekerjaan yang jelek oleh kontraktor

3. Kesalahan pengelolaan material oleh kontraktor

4. Kekurangan tenaga kerja oleh kontraktor

5. Hujan deras/lokasi pekerjaan yang tergenang air

6. Keadaan tanah yang berbeda dari yang diharapkan

7. Pekerjaan tambahan yang diminta oleh client owner 
8. Perubahan dalam pekerjaan plumbing, struktur, elektrikal

9. Kesalahan dalam perencanaan dan spesifikasi

10. Ketidak jelasan perencanaan dan spesifikasi

11. Perubahan-perubahan dalam perencanaan dan spesifikasi

12. Perubahan metode kerja oleh kontraktor

13. Kesalahan dalam menginterprestasikan gambar atau spesifikasi

14. Perencanaan schedule pekerjaan yang kurang baik oleh kontraktor

15. Produktifitas yang kurang optimal dari kontraktor

16. Perubahan scope pekerjaan konsultan

17. Pemogokan yang dilakukan oleh kontraktor

18. Memperbaiki pekerjaan yang sudah selesai

19. Memperbaiki kerusakan suatu pekerjaan akibat pemogokan

20. Terlambatnya persetujuan shop drawing oleh konsultan

Sedangkan menurut Assaf (1995), faktor-faktor penyebab keterlambatan pada proyek konstruksi bangunan gedung yang disebabkan oleh faktor bahan material adalah:

a. Kekurangan bahan/material konstruksi

b. Perubahan tipe dan spesifikasi material

c. Lambatnya pengiriman material

d. Kerusakan material akibat penyimpanan

Menurut Kraiam dan Dickman yang di kutip dari Wahyudi (2006), keterlambatan dapat dibagi menjadi tiga jenis utama, yaitu :

1. Keterlambatan yang tidak dapat dimaafkan (Non excusable delays). Non excusable delays adalah keterlambatan yang diakibatkan oleh tindakan, kelalaian, atau kesalahan kontraktor.

Faktor-faktor yang termasuk kedalam non excusable delays, yaitu:

a. Identifikasi, durasi, dan rencana urutan kerja tidak lengkap dan tidak tersusun dengan baik.

b. Ketidaktepatan perencanaan tenaga kerja. 
c. Kualitas tenaga kerja yang buruk.

d. Keterlambatan penyediaan alat/material akibat kelalaian kontraktor.

e. Jenis peralatan yang digunakan tidak sesuai dengan proyek.

f. Mobilisasi sumber daya yang lambat.

g. Banyak hasil pekerjaan yang harus diulang/diperbaiki karena cacat/salah.

h. Kesulitan finansial.

i. Kurangnya pengalan kontraktor.

j. Koordinasi dan komunikasi yang buruk dalam organisasi kontraktor.

k. Metode konstruksi/teknik pelaksanaan yang kurang tepat/salah.

1. Kecelakaan kerja yang terjadi pada pekerja.

2. Kesalahan yang dapat dimaafkan (Excusable delays).

Excusable delays adalah keterlambatan yang disebabkan oleh kejadiankejadian diluar kendali baik pemilik maupun kontraktor. Pada kejadian ini, kontraktor mendapat kompensasi berupa perpanjagan waktu saja.

Faktor-faktor yang termasuk dalam excusable delays, yaitu:

a. Terjadinya hal-hal yang tidak terduga seperti banjir, gempa bumi, tanah longsor, kebakaran, cuaca buruk.

b. Lingkungan sosial politik yang tidak stabil.

c. Respon dari masyarakat sekitar yang tidak mendukung adanya proyek.

3. Kesalahan yang layak mendapat ganti rugi (Compensable delays).

Compensable delays adalah keterlambatan yang diakibatkan tindakan, kelalaian atau kesalahan pemilik. Pada kejadian ini, kontraktor biasanya mendapatkan kompensasi berupa perpanjangan waktu dan tambahan biaya operasional yang perlu selama keterlambatan pelaksanaan tersebut.

Faktor-faktor yang termasuk kedalam compensable delays, yaitu:

a. Penetapan pelaksanaan jadwal proyek yang amat ketat.

b. Persetujuan izin kerja yang lambat.

c. Perubahan lingkup pekerjaan/detail konstruksi.

d. Sering terjadi penundaan pekerjaan. 
e. Keterlambatan penyediaan material.

f. Dana dari pemilik yang tidak mencukupi.

g. Sistem pembayaran pemilik ke kontraktor yang tidak sesuai kontrak.

h. Cara inspeksi/kontrol birokratis oleh pemilik.

Menurut Donal. S. Barie (1984), keterlambatan dapat disebabkan oleh pihakpihak yang berbeda, yaitu:

1. Pemilik atau wakilnya (delay caused by owner or his agent). Bila pemilik atau wakilnya menyebabkan suatu keterlambatan, misalnya karena terlambat pemberian gambar kerja atau keterlambatan dalam memberikan persetujuan terhadap gambar, maka kontraktor umumnya akan diperkenankan untuk mendapatkan perpanjangan waktu dan juga boleh mengajukan tuntutan yang sah untuk mendapatkan kompensasi ekstranya.

2. Keterlambatan oleh pihak ketiga yang diperkenankan (excusable triedparty delay). Sering terjadi keterlambatan yang disebabkan oleh kekuatan yang berbeda diluar jangkauan pengendalian pihak pemilik atau kontraktor. Contoh yang umumnya tidak dipersoalkan lagi diantaranya adalah kebakaran, banjir, gempa bumi dan hal lainnya. Hal-hal lainnya yang sering kali menjadi masalah perselisihan meliputi pemogokan, embargo untuk pengangkutan, kecelakaan dan keterlambatan dalam menyerahkan yang bisa dimengerti. Termasuk pula yang tidak dapat dimasukan dalam kondisi yang telah ada pada saat penawaran dilakukan dan keadaan cuaca buruk. Dalam hal ini dapat disetujui, tipe keterlambatan dari tipe-tipe ini umumnya menghasilkan perpanjangan waktu namun tidak disertai dengan kompensasi tambahan.

3. Keterlambatan yang disebabkan kontraktor (contractor-caused delay). Keterlambatan semacam ini umumnya akan berakibat tidak diberikannya perpanjangan waktu dan tidak ada pemberian suatu kompensasi tambahan. Bila pada situasi ekstrim maka hal-hal ini akan menyebabkan terputusnya ikatan kontrak. 
Menurut Scott (1997), keterlambatan suatu pelaksanaan proyek dapat diklasifikasikan menjadi tiga hal yaitu compensable delay, non-compensable delay dan concurrent delay.

Menurut Popescu dan Charoengam (1995), apabila dilihat berdasarkan tanggung jawabnya, keterlambatan dapat diklasifikasikan menjadi excusable delay, non-excusable delay, dan concurrent delay.

Dari beberapa faktor penyebab keterlambatan yang telah dijelaskan oleh para ahli sebelumnya, maka penulis merumuskan beberapa faktor yang akan dijabarkan dan dipilih untuk kuesioner, antara lain :

1. Penyebab keterlambatan menurut Levis dan Artherley (1996):

a. Keterlambatan pembayaran oleh client owner

b. Pelaksanaan tahapan pekerjaan yang jelek oleh kontraktor

c. Kesalahan pengelolaan material oleh kontraktor

d. Kekurangan tenaga kerja oleh kontraktor

e. Hujan deras/lokasi pekerjaan yang tergenang air

- Lokasi proyek yang sulit dijangkau

f. Keadaan tanah yang berbeda dari yang diharapkan

g. Perubahan dalam pekerjaan plumbing, struktur, dan elektrikal

h. Perubahan metode kerja oleh kontraktor

i. Kesalahan dalam menginterprestasikan gambar atau spesifikasi

j. Perencanaan schedule pekerjaan yang kurang baik oleh kontraktor

k. Pemogokan kerja yang dilakukan oleh kontraktor

1. Memperbaiki pekerjaan yang sudah selesai

m. Memperbaiki kerusakan suatu pekerjaan akibat pemogokan

n. Terlambatnya persetujuan shop drawing oleh konsultan

2. Faktor keterlambatan menurut Assaf (1995) :

a. Kekurangan bahan/material konstruksi

- Ketidaktersediaan material dilokasi

- Jumlah material yang dikirim suplier tidak sesuai 
b. Lambatnya pengiriman material

- Keterlambatan pemesanan material

c. Kerusakan material akibat penyimpanan

3. Faktor keterlambatan menurut Kraim dan Dickman yang dikutip dari Wahyudi (2006) :

a. Ketidaktepatan perencanaan tenaga kerja

b. Kualitas tenaga kerja yang buruk

c. Jenis peralatan yang digunakan tidak sesuai dengan proyek

- Kerusakan peralatan

- Peralatan tidak tersedia tepat waktu

- Peralatan tidak produktif

d. Kesulitan finansial

- Modal kontraktor yang tidak mencukupi

- Administrasi keuangan pada kontraktor

e. Kurangnya pengalaman kontraktor

f. Lingkungan sosial politik yang tidak stabil

g. Respon dari masyarakat sekitar yang tidak mendukung adanya proyek.

h. Kecelakaan kerja yang terjadi terhadap pekerja

- Kurangnya kontrol terhadap keselamatan kerja

\section{PEMBAHASAN}

Dari kuesioner yang disebarkan pada 28 responden perusahaan jasa konstruksi, berikut ini adalah pemetaan dan analisis terhadap sub-faktor penyebab keterlambatan pekerjaan konstruksi gedung, meliputi; faktor bahan dan material, faktor lingkungan, faktor keuangan, faktor perubahan, faktor tenaga kerja, faktor waktu dan kontrol, dan faktor peralatan.

Tabel 1: Penafsiran Nilai Mean, Median, Modus

\begin{tabular}{|c|c|}
\hline Nilai & Penafsiran \\
\hline 0 & Tidak Berpengaruh \\
\hline $0-1,5$ & Cukup Berpengaruh \\
\hline
\end{tabular}




\begin{tabular}{|c|c|}
\hline $1,5-2$ & Berpengaruh \\
\hline $2,5-3$ & Sangat Berpengaruh \\
\hline
\end{tabular}

Sumber : Hasil Analisis (2016)

Tabel 2 : Hasil analisis faktor bahan dan material

\begin{tabular}{|l|c|c|c|c|}
\hline Faktor & Jumlah & Mean & Median & Modus \\
\hline Kekurangan Bahan Konstruksi & 69 & 2,46 & 3 & 3 \\
\hline Lambatnya Pengiriman Material & 65 & 2,32 & 2 & 3 \\
\hline Ketidaktersediaan Material di Lokasi & $\mathbf{7 2}$ & $\mathbf{2 , 5 7}$ & $\mathbf{3}$ & $\mathbf{3}$ \\
\hline Keterlambatan Pemesanan Material & 60 & 2,14 & 2 & 2 \\
\hline $\begin{array}{l}\text { Jumlah Material yang Dikirim Supplier tidak } \\
\text { sesuai }\end{array}$ & 56 & 2 & 2 & 3 \\
\hline Kerusakan Material Akibat Penyimpanan & 51 & 1,82 & 2 & 2 \\
\hline Kesalahan Pengelolaan Material Oleh Kontraktor & 54 & 1,93 & 2 & 2 \\
\hline \multicolumn{1}{|r|}{ Skor total } & 427 & & & \\
\hline
\end{tabular}

Sumber : Hasil Analisis (2016)

Tabel 3 : Hasil analisis faktor lingkungan

\begin{tabular}{|l|c|c|c|c|}
\hline Faktor & Jumlah & Mean & Median & Modus \\
\hline $\begin{array}{l}\text { Hujan deras/ lokasi yang } \\
\text { tergenang air }\end{array}$ & $\mathbf{6 5}$ & $\mathbf{2 , 3 2}$ & $\mathbf{2}$ & $\mathbf{3}$ \\
\hline $\begin{array}{l}\text { Aspek sosial (perang, kerusuhan) di } \\
\text { lokasi }\end{array}$ & 54 & 1,93 & 2 & 2 \\
\hline Lokasi proyek yang sulit di jangkau & 50 & 1,79 & 2 & 2 \\
\hline $\begin{array}{l}\text { Respon dari Masyarakat yang tidak } \\
\text { mendukung proyek tsb }\end{array}$ & 59 & 2,11 & 2 & 3 \\
\hline $\begin{array}{l}\text { Keadaan tanah yang beda dari yang } \\
\text { diharapkan Skor total }\end{array}$ & 47 & 1,68 & 2 & 2 \\
\hline \multicolumn{1}{|c|}{ Sha } & & & \\
\hline
\end{tabular}

Sumber : Hasil Analisis (2016)

Tabel 4 : Hasil analisis faktor keuangan

\begin{tabular}{|l|c|c|c|c|}
\hline Faktor & Jumlah & Mean & Median & Modus \\
\hline $\begin{array}{l}\text { Modal Kontraktor yang } \\
\text { tidak mencukupi }\end{array}$ & $\mathbf{6 1}$ & $\mathbf{2 , 1 8}$ & $\mathbf{2}$ & $\mathbf{3}$ \\
\hline $\begin{array}{l}\text { Administrasi keuangan pada } \\
\text { kontraktor }\end{array}$ & 48 & 1,71 & 2 & 2 \\
\hline $\begin{array}{l}\text { Keterlambatan pembayaran } \\
\text { oleh client owner }\end{array}$ & 58 & 2,07 & 2 & 3 \\
\hline \multicolumn{1}{|c|}{ Skor total } & 167 & & & \\
\hline
\end{tabular}

Sumber : Hasil Analisis (2016) 
Tabel 5 : Hasil analisis faktor perubahan

\begin{tabular}{|c|c|c|c|c|}
\hline Faktor & Jumlah & Mean & Median & Modus \\
\hline $\begin{array}{l}\text { Modal Kontraktor yang tidak } \\
\text { mencukupi }\end{array}$ & 61 & 2,18 & 2 & 3 \\
\hline $\begin{array}{l}\text { Administrasi keuangan pada } \\
\text { kontraktor }\end{array}$ & 48 & 1,71 & 2 & 2 \\
\hline $\begin{array}{l}\text { Keterlambatan pembayaran } \\
\text { oleh client owner }\end{array}$ & 58 & 2,07 & 2 & 3 \\
\hline Skor total & 167 & & & \\
\hline
\end{tabular}

Sumber : Hasil Analisis (2016)

Tabel 6 : Hasil analisis faktor tenaga kerja

\begin{tabular}{|l|c|c|c|c|}
\hline Faktor & Jumlah & Mean & Median & Modus \\
\hline $\begin{array}{l}\text { Kualitas tenaga kerja yang } \\
\text { buruk }\end{array}$ & 68 & 2,43 & 3 & 3 \\
\hline $\begin{array}{l}\text { Pemogokan kerja yang } \\
\text { dilakukan oleh pekerja }\end{array}$ & 62 & 2,21 & 2 & 3 \\
\hline $\begin{array}{l}\text { Tenaga kerja yang minim } \\
\text { keahlian dan pengalaman }\end{array}$ & 65 & 2,32 & 2,5 & 3 \\
\hline $\begin{array}{l}\text { Ketidaktepatan Perencanaan } \\
\text { tenaga kerja }\end{array}$ & 61 & 2,18 & 2 & 2 \\
\hline $\begin{array}{l}\text { Kekurangan tenaga kerja oleh } \\
\text { kontraktor }\end{array}$ & 64 & 2,29 & 2 & 3 \\
\hline \multicolumn{1}{|c|}{ Skor total } & 320 & & & \\
\hline
\end{tabular}

Sumber : Hasil Analisis (2016)

Tabel 7 : Hasil analisis faktor waktu dan kontrol

\begin{tabular}{|l|c|c|c|c|}
\hline Faktor & Jumlah & Mean & Median & Modus \\
\hline $\begin{array}{l}\text { PerencanaanSchedule yang kurang } \\
\text { baik oleh kontraktor }\end{array}$ & 53 & 1,89 & 2 & 2 \\
\hline $\begin{array}{l}\text { Terlambatnya Persetujuan Shop } \\
\text { drawing oleh konsultan }\end{array}$ & 57 & 2,04 & 2 & 2 \\
\hline $\begin{array}{l}\text { Kurangnya kontrol terhadap } \\
\text { keselamatan kerja }\end{array}$ & 50 & 1,79 & 2 & 2 \\
\hline $\begin{array}{l}\text { Produktifitas yang kurang optimal } \\
\text { dari kontraktor }\end{array}$ & 59 & 2,11 & 2 & 2 \\
\hline $\begin{array}{l}\text { Memperbaiki pekerjaan yang sudah } \\
\text { selesai }\end{array}$ & 46 & 1,64 & 2 & 2 \\
\hline $\begin{array}{l}\text { Pelaksanaan pekerjaan tahapan yang } \\
\text { jelek oleh kontraktor }\end{array}$ & 60 & 2,14 & 2 & 2 \\
\hline $\begin{array}{l}\text { Memperbaiki Kerusakan suatu } \\
\text { pekerjaan akibat pemogokan }\end{array}$ & 54 & 1,93 & 2 & 2 \\
\hline \multicolumn{1}{|c|}{ Skor total } & 379 & & & \\
\hline
\end{tabular}

Sumber : Hasil Analisis (2016)

Tabel 8 : Hasil analisis faktor peralatan

\begin{tabular}{|l|l|l|l|l|}
\hline Faktor & Jumlah & Mean & Median & Modus \\
\hline
\end{tabular}




\begin{tabular}{|c|c|c|c|c|}
\hline Kerusakan peralatan & 59 & 2,11 & 2 & 3 \\
\hline Peralatan tidak tersedia tepat waktu & 60 & 2,14 & 2 & 3 \\
\hline Peralatan tidak produktif & 62 & 2,21 & 2 & 3 \\
\hline Skor total & 181 & & & \\
\hline
\end{tabular}

Tabel 9 : Data perbandingan faktor penyebab keterlambatan

\begin{tabular}{|c|l|c|c|c|c|}
\hline No & \multicolumn{1}{|c|}{ Faktor } & Mean & Median & Modus & Total Skor \\
\hline 1 & Tenaga Kerja & 2,29 & 2,00 & 3 & 7,29 \\
\hline 2 & Bahan dan Material & 2,18 & 2,00 & 3 & 7,18 \\
\hline 3 & Peralatan & 2,15 & 2,00 & 3 & 7,15 \\
\hline 4 & Perubahan & 1,95 & 2,00 & 3 & 6,95 \\
\hline 5 & Keuangan & 1,99 & 2,00 & 2 & 5,99 \\
\hline 6 & Lingkungan & 1,96 & 2,00 & 2 & 5,96 \\
\hline 7 & Waktu dan Kontrol & 1,93 & 2,00 & 2 & 5,93 \\
\hline
\end{tabular}

Dari hasil analisis terhadap faktor bahan dan material diatas, maka faktor "Ketidaktersediaan material di pasaran" menjadi faktor yang dominan dengan nilai sebesar 72, mean 2,57, median 3 , modus 3 .

Dari hasil analisis terhadap faktor lingkungan diatas, maka faktor "Hujan deras/lokasi yang tergenang air" menjadi faktor yang dominan dengan nilai sebesar 65, mean 2,32, median 2, dan modus 3 .

Dari hasil analisis terhadap faktor keuangan diatas, maka faktor "Modal kontraktor yang tidak mencukupi” menjadi faktor yang dominan dengan nilai sebesar 61, mean 2,18, median 2, modus 3 .

Dari hasil analisis terhadap faktor perubahan diatas, maka faktor "Kesalahan dalam menginterpresentasikan gambar atau spesifikasi" menjadi faktor yang dominan dengan nilai sebesar 68 , mean 2,43, median 3, modus 3 . 
Dari hasil analisis terhadap faktor tenaga kerja, maka faktor "Kualitas tenaga kerja yang buruk" menjadi faktor yang dominan dengan nilai sebesar 68 dan nilai mean diangka 2,43, median 3,00 dan modus 3,00.

Dari hasil analisis terhadap faktor waktu dan kontrol diatas, maka faktor "Pelaksanaan tahapan yang jelek oleh kontraktor" menjadi faktor yang dominan dengan nilai sebesar 60 , mean 2,14 , median 2 , modus 2

Dari hasil analisis terhadap faktor peralatan diatas, maka faktor "Peralatan tidak produktif" menjadi faktor yang dominan dengan nilai sebesar 62, mean 2,21, median 2 , modus 3

\section{KESIMPULAN}

Dari hasil penelitian faktor penyebab keterlambatan pekerjaan konstruksi di kota Jambi menurut persepsi kontraktor, dapat ditarik beberapa kesimpulan, antara lain :

1. Pada uji validitas, diketahui nilai validitas sub-faktor yang terdapat pada faktor-faktor penyebab keterlambatan menyatakan bahwa $r x y>r$ tabel, yang berarti semua data bisa dikatakan valid dan pada uji reliabilitas, semua data yang diuji menunjukan bahwa nilai Cronbach's Alpha > r tabel, yang mana dapat dikatakan bahwa data tersebut reliabel.

2. Faktor Bahan dan Material mendapatkan skor total 7,18 dan sub-faktor yang paling berpengaruh adalah Ketidaktersediaan Material di Lokasi dengan skor mean 2,57, median 3,00 dan modus 3,00.

3. Faktor Lingkungan mendapatkan skor total 5,96, dan sub-faktor yang paling berpengaruh adalah Hujan Deras/Lokasi yang Tergenang Air dengan skor mean 2,32, median 2,00 dan modus 3,00.

4. Faktor Keuangan mendapatkan skor total 5,99, dan sub-faktor yang paling berpengaruh adalah Modal Kontraktor yang Tidak Mencukupi dengan skor mean 2,18, median 2,00 dan modus 3,00. 
5. Faktor Perubahan mendapatkan skor total 6,95, dan sub-faktor yang paling berpengaruh adalah Kesalahan dalam Menginterpresentasikan Gambar atau Spesifikasi dengan skor mean 2,43, median 3,00 dan modus 3,00.

6. Faktor Tenaga Kerja mendapatkan skor total tertinggi yaitu 7,29 dan subfaktor yang paling berpengaruh adalah Kualitas Tenaga Kerja yang Buruk dengan skor mean 2,43, median 3,00 dan modus 3,00.

7. Faktor Waktu dan Kontrol mendapatkan skor total 5,93, dan sub-faktor yang paling berpengaruh adalah Pelaksanaan Pekerjaan Tahapan yang Jelek oleh Kontraktor dengan skor mean 2,14, median 2,00 dan modus 2,00 .

8. Faktor Peralatan mendapatkan skor total 7,15, dan sub-faktor yang paling berpengaruh adalah Peralatan tidak Produktif dengan skor mean 2,21, median 2,00 dan modus 3,00.

9. Sub-faktor ketidaktersediaan material di lokasi menjadi sub-faktor paling berpengaruh dari 33 sub-faktor lainnya. Dari 28 responden, 64,3\% diantaranya menyatakan bahwa sub-faktor tersebut menjadi faktor yang sangat berpengaruh, $28,6 \%$ menyatakan berpengaruh dan $7,1 \%$ menyatakan cukup berpengaruh.

10. Setelah melewati proses analisis, faktor-faktor penyebab keterlambatan konstuksi dapat diurutkan mulai dari yang sangat berpengaruh sampai dengan berpengaruh, berdasarkan skor total dan analisis tendensi central (mean, median, modus), dapat diurutkan sebagai berikut; faktor tenaga kerja, faktor bahan dan material, faktor peralatan, faktor perubahan, faktor keuangan, faktor waktu dan kontrol, faktor lingkungan.

\section{DAFTAR PUSTAKA}

Amperawan, R. (1999). Studi Keterlambatan Kontraktor dalam Melaksanakan Proyek Konstruksi di Daerah Istimewa Yogyakarta.

Arikunto, S. (2010). Prosedur Penelitian : Suatu Pendekatan Praktik (ed.revisi). Jakarta : Rineka Cipta

Assaf, C. (1995). Cause of Delay in Large Building Construction Project. 
Dipohusodo, Istimawan. (1996). Manajemen proyek \& konstruksi (vol.1). Yogyakarta: Kanisius.

Dipohusodo, Istimawan. (1996). Manajemen proyek \& konstruksi (vol.2). Yogyakarta: Kanisius.

Kountur, Ronny. (2007). Metode penelitian untuk penyusunan skripsi dan tesis (ed.revisi). Jakarta: PPM.

Kurniawan, Trianto. (2011). Apa itu Usaha Jasa Konstruksi?. Bloggerized by Lasantha. Indonesia.

Levis and Atherly. (1996). Langford.

Santoso, Christiani. (2014). Analisis faktor keterlambatan penyelesaian proyek pembangunan Granf Ballroom Royal Ambarukmo. Jurnal ilmiah Teknik Sipil. Yogyakarta.

Soeharto, Imam. (1995). Manajemen proyek. Jakarta: Erlangga.

Sugiyono. (2011). Statistika Untuk Penelitian. Bandung: Alfabeta.

Sugiyono. (2006). Metode Penelitian Pendidikan, Pendekatan Kuantitatif, Kualitatif dan $R \& D$. Bandung : Alfabeta.

Wahyudi, R dan Indra Yono, C. (2006). Pengaruh Keterlambatan Proyek terhadap Pembengkakan Biaya Proyek. Jurnal Ilmiah Teknik Sipil.Surabaya: Universitas Kristen Petra.

Wulfram, Ervianto. (2002). Manajemen proyek konstruksi (ed.revisi). Yogyakarta: C. V Andi offset. 